\title{
FOSTERING QUALITY TEACHERS UNDER THE SETTING OF INDONESIAN CLASSROOMS
}

\author{
KartikaNuswantara
}

\begin{abstract}
Being a teacher could be committed by anyone who has the passion in teaching, so that any situations in reality would not hamper him from the struggle to be a good teacher. Classroom is the laboratory for the teachers for their personal development. Students from whom the teachers can learn are their other assets. If an unfortunate system keeps going without any authority from the side of the teacher to change, being a quality teacher should still become teachers' efforts to realize.
\end{abstract}

Keywords: fostering, quality teachers, good teachers, Indonesia classroom, rote learning, centralized teacher recruitment

"A teacher who loves learning earns the right and the ability to help others learn."-Ruth Beechick, Easy Start in Arithmetic/K-.

The quote above would be an ample support for teachers to make learning a never-ending process. Teacherswould gain more so that teaching is no longer containing dull routine exercises but teaching would be aninseparable learning process in which the classrooms would become a mediocre laboratory eliciting various sources of learning for teachers. Good teachers would be sensitive to see every single problem emerging in every process of learning as a source for enrichment in terms of personal capacity. Classroom can be a live book for teachers, as through the class teachers can read the knowledge about management of the classroom, student-teacher/student-student interaction, and so on. Only those who are really aware that the ability to learn from any experience hampering the process of teaching can be used as a source to learn then it can lead teachers to reach all the capacities of good teachers.

A warning for today teachers comes from Jamil, et.al., who have stated that teachers now are under a growing pressure to perform. This is due to the expectations that are growing higher and greater in terms of pressures for teachers to perform effectively in classroom as it is. To be able to perform implies specific capacities needed by teachers to acquire. In one recent study in department of 
medicine stated in Azer (2005), it was figured out that the most highly regarded teachers as good teachers when they occupy certain capacities, including enthusiastic, friendly, easy-going, able to develop rapport with learners, committed to the growth of their students, approachable, interested in learners as people, and alwaysconscious of their status as role models. At the same time, the study also attempted to uncover the unexpected capacities for teachers, namely being quiet, being overextended, havingdifficulty remembering names and being impatient andimpulsive.Thus, it is not an exaggeration to say that teacher is not just an occupation but it is a career that provides challenges, excitement, personal reward and a chance to encourage and support others to achieve their goals, and those can only be attained if the person, the teacher, is willing to keep her/himself learning and enhancing the knowledge from various resources, not to mention from her/his own classroom.

Speaking about the quality of good teachers Azer (2005) has listed 12 qualities that teachers should have (see table 1). The qualities have been fostered by various efforts including personal prizes, grants for research in education, or fundingto attend professional development courses. Building links among educators either local or international should also be fostered to challenge teachers for enhancing their personal qualities. However, there is one aspect that needs to be reconsidered when profiles of good teacher are attempted to be elicited. Culture or tradition would become a determinant factor for eliciting the characteristic of good teachers. For example, in a study called The Good Teacher, Moore (2004) defines good teacher in the version of England culture, that there are three models representing the qualities namely 'competent craftsperson' model, a 'reflective practitioner' model, and a 'charismatic' model. Another example, in China, Chinese Confucian tradition defines a good teacher as a moral authority. Hence, in Chinese schooling there is a strong assumption of respect on the part of the learner. On the other hand, a teacher in the Chinese/Japanese Zen Buddhist tradition is not so much a moral authority as a cognitive revolutionary. In this tradition the teacher tries to provoke a breakthrough in the student's perception, and may use outrageous jokes and paradoxes to do so (Watts, 1957 in Connell, 2009). Then, another example is 
taken from the Australian case, in which the ideas of the good teacher have shifted historically. During the period of collonialism in Australia, instead of teachers who were supposed to be the agent to drive the pedagogical activities in the classroom, the school curriculum was quite determinant in determining what and how to learn in the classroom. In other words, there is an authority from the outside of the class that could drive the process, while teachers were inactive party who could move tightly based on what were stated on the so called curriculum without being able to modify in such a way to meet the need of the classroom. At the same vein, students were also seen as obedient individuals who would follow what the teachers asked them to do unless they were adressed as students without any respects to the teachers. Thus, moral value in education at that time was seen from the obedience and respecteablity paid to the teachers, then from the teachers, strick orders were given in order that curriculum should be followed strictly, no matter whether it met the students' learning demands or not. (Hyams, 1979 in Connell, 2009). This was not accidental. The new mass school systems were interventions into a turbulent colonial society, designed to achieve social control over working-class and rural youth who might easily escape from it. Little value was placed on a capacity for independent thought. The good teacher at this time was, above all, an obedient servant of the authorities. From the examples, China might be resemblance to those in the countries in Southeast Asia.

Yet, the obedience of the teachers toward the strict curriculum and the overrespect from the students to the teachers are no longer appropriate with the situation of today era where people are getting more and more open and find themselves free to express their mind. This, off course, has affected the way the education practitioners think; they are no longer detained into the outdated education as it was in the era of collonianilsm. Both teachers and students are seen as active and dynamic entities in education that must be intricately connected to build a live classroom. At the first place, to enable classroom to be lively, teachers are the first place to initiate; then it bears the idea to promote the capacity of good teachers, and among many characteristics, the following table lists the one that is selected in the 
article to be the underlining basis to figure out the characteristics needed for being good teachers, not to mention good teachers for Indonesian classrooms.

Table 1. 12 Qualities of Good Teachers

\begin{tabular}{|c|c|}
\hline Qualities & Description \\
\hline Being committed to the work & $\begin{array}{l}\text { Focusing on educational needs of the students } \\
\text { Working with passion } \\
\text { Being keen to uphold the university's values } \\
\text { Being enthusiastic about work and about } \\
\text { teaching }\end{array}$ \\
\hline Encouraging and appreciating diversity & $\begin{array}{l}\text { Not stereotyping or speaking negatively of others } \\
\text { Nurturing and encouraging diversity } \\
\text { Seeking and encouraging understanding of, and } \\
\text { respect forpeople of diverse backgrounds }\end{array}$ \\
\hline Interacting and communicating respect & $\begin{array}{l}\text { Communicating effectively with others } \\
\text { Encouraging input from others, listening deeply } \\
\text { and givingcredit for their contributions } \\
\text { Acting with integrity } \\
\text { Providing a model of high ethical standards } \\
\text { Showing a caring attitude }\end{array}$ \\
\hline Motivating students and co-workers & $\begin{array}{l}\text { Encouraging students to achieve their goals } \\
\text { Providing constructive feedback } \\
\text { Monitoring progress of students and fosters their } \\
\text { success }\end{array}$ \\
\hline $\begin{array}{l}\text { Bringing a wide range of skills and talents to } \\
\text { teaching }\end{array}$ & $\begin{array}{l}\text { Teaching is clearly presented and stimulates } \\
\text { high-order thinking skills } \\
\text { Presenting difficult concepts comprehensibly } \\
\text { Bringing appropriate evidence to the critique } \\
\text { Teaching memorably }\end{array}$ \\
\hline Demonstrating leadership in teaching & $\begin{array}{l}\text { Contributing to course design and structure } \\
\text { Contributing to publications on education } \\
\text { Evidence of self-development in an educational } \\
\text { context } \\
\text { Demonstrating creativity in teaching strategies } \\
\text { BeingCommitted to professional development in } \\
\text { education }\end{array}$ \\
\hline $\begin{array}{l}\text { Encouraging an open and trusting learning } \\
\text { environment }\end{array}$ & $\begin{array}{l}\text { Creating a climate of trust } \\
\text { Encouraging students to learn from mistakes } \\
\text { Helping students redefine failure as a learning } \\
\text { experience } \\
\text { Encouraging student questions and engagement } \\
\text { in the } \\
\text { learning process } \\
\text { Encouraging student growth with appropriate } \\
\text { behaviorbased feedback }\end{array}$ \\
\hline Fostering critical thinking & $\begin{array}{l}\text { Teaching students how to think, not what to think } \\
\text { Encouraging students to organize, analyze and } \\
\text { evaluate } \\
\text { Exploring with probing questions } \\
\text { Discussing ideas in an organized way } \\
\text { Helping students to focus on key issues } \\
\text { Trains students in strategic thinking }\end{array}$ \\
\hline Encouraging creative work & $\begin{array}{l}\text { Motivating students to create new ideas } \\
\text { Fostering innovation and new approaches }\end{array}$ \\
\hline
\end{tabular}




\begin{tabular}{|c|c|}
\hline Emphasizing teamwork & $\begin{array}{l}\text { Building links at national and international levels } \\
\text { in education } \\
\text { Encouraging students to work in teams } \\
\text { Encouraging collaborative learning }\end{array}$ \\
\hline Seeking continually to improve teaching skills & $\begin{array}{l}\text { Seeking to learn and incorporate new skills, and } \\
\text { information teaching } \\
\text { Seeking feedback and criticism } \\
\text { Keeping up to date in specialty }\end{array}$ \\
\hline Providing positive feedback & $\begin{array}{l}\text { Listening to students and discovers their } \\
\text { educational needs } \\
\text { Valuing students, never belittles } \\
\text { Providing constructive feedback } \\
\text { Helping and supporting people to grow } \\
\text { Teaching students how to monitor their own } \\
\text { progress. }\end{array}$ \\
\hline
\end{tabular}

Realizing the ideal characteristics enlisted in the above table, teachers cannot be left alone arriving at the expected capacities named characteristics of good teachers. They must be supported by the authority as well as the classroom itself. For example, being a good teacher means being able to seek continual efforts to improve teaching skills; therefore, teachers will improve their capacity only if there is support coming from the policy maker. If the authority provides facilities for teachers to recharge or to upgrade the skills they have so that they are able to raise their personal quality, it will be accommodating to encourage teachers to be the good ones. On the other hand, if the authority does not show serious efforts to improve the systems that enable the growing capacity of teachers, the recomendations for promoting good teachers would never come to light.

Henceforth, the success of teachers to promote themselves to be good teachers is not a single effort, but there is a constellation between teachers and the system governing education practices. This article attempts to see the quality teachers from two different angles, the premises and practices.

\section{Teachers Working in the Culture of Indonesian Classrooms.}

A classroom is the laboratory for teachers to tailorto become a resourceful place for both teachers and students to gain knowledge. Teachers are supposed to be the director who should drive the play into a process where every single individual in the play can take important and determining roles. However, in reality there might be some constrains making teachers not be able to take a full control to make 
students involve actively in proceeding their learning process. Some of the constraints might lie in the status of the teacher and model of the assessment in Indonesia.

A centralized and top-down system is the system approved in Indonesia for recruiting, employing as well as deploying teachers in Indonesia (Gardiner, 2000); therefore, teachers are recruited and employed by a government body, such as the Ministry of National Education (MONE) or the Ministry of Religious Affairs (MORA), and become civil servant (pegawai negeri). Zulfikar (2009) states that such a system is less advantageous for keeping the good quality of teachers. The system, according to him, needs to be reformed for the reasons that the elected teachers do not fit the needs of the class. The civil servant is elected through civil servant test in which the test given is not about how to teach under pedagogic theories but about Indonesian civic education, English as a foreign language and the Indonesian language. It is undeniable that those subjects are important but they fail to really measure the pedagogic capacity of the teachers. In teaching mathematics, for instance, teachers need to have ample knowledge about mathematics rather than English that is tested in the civil servant test. Therefore, in his article, Zulfikar (2009) proposes two components need to be well considered in recruitment of teachers.

First, considering the specific conditions and needs of every school, teacher recruitment system needs to be decentralised. This centralised recruitment is criticised for not being able to produce teachers who suit particular school cultures and settings; the centralised recruitment also forces teachers to submit themselves to disciplinary regulations imposed by those civil servant bodies (MORA and MONE). Second, the test content should also be revisited. If so far the test only tests the understanding of the candidates about civic education and languages, the test should be made closer to the demand. If the recruitment is aimed to seek math teachers, the test should be directed to test the capacity of the candidates in coping with mathematical problems. In other words, the test should be aimed to test the cognitive capacity. Besides, it might be relevant to test the pedagogical skill so that the candidate can show the underpinning knowledge on how to teach in the class, and if 
neccesary they are requested to handle the class so that the ability to drive the class activity can be figured out early. As a result, teachers of appropriate capacity can be found to fit the class' needs. Thus, it might be relevant to suggest that the test content should be reformed to represent appropriate content knowledge and pedagogical ability. Zulfikar also suggestsat least four phases for recruiting teachers: first, the candidates should provide schools with their curriculum vitae, teaching portfolio and qualification documentation; then, there must be a series of interviews by the senior teachers and the school principal; and a test of content knowledge, and a test of pedagogical knowledge through performance tests where candidates would be scheduled to teach for some minutes in front of examiners who are senior and experienced teachers. These four phases of recruitment would enable the school committee to judge prospective teachers who might suit the school and to recruit teachers who would understand and be responsible in their teaching obligations.

Another constraint is the status of national examination in Indonesian education system. In-class examination is employed to assess student academic achievement, in which the test questions are set centrally (Gardiner, 2000). The test format selected is mostly multiple choice questions; few require written essays. Such examination is administered at the end of Year 6, at the end of Year 9 (grade 3 of SMP or junior high school) and at the end of Year 12 (grade 3 of SMU or senior high school). Such a test is considered as the constraint along with the criticism on the implementation of the national examination. Oey-Gardiner (2005) and Lie (2004) are among those who assert that the implementation of a national examination is a poor way to measure students' academic achievement. The system of the national examination has been accused of aggravating conditions of Indonesian education because it measures students' cognitive ability only, for example, the ability to memorize certain topics of the lesson (Daud, 2009; Khalifa, 2009; Soaloon, 2009).

Pertinent to the fact about the status of the teacher recruitment and the model of national examination in Indonesia, it can be surmised that the culture of Indonesia classroom is signified by two unfortunate conditions, namely centralisation of teacher recruitmet that affects the appropriacy between the quality of the teaches and 
the demands of the classroom; and the learning model that still shadows the education system in Indonesia and that is due to the model of the national examination which undeniably lead to the use of learning strategy aimed to cope with particular topics in the lessons through students' memorization skills. Thus, speaking about the culture of Indonesia classroom, inappropriate teacher capacity and rote learning seem become a major issue in many Indonesia classrooms.

\section{Reforming the System, reforming the Quality of the Teachers}

a. Reforming the system for Teacher Recruitment

Thingking about fostering the good quality of teachers in Indonesia, there should be any endorsement from the side of the policy makers who hold the right to control the system of education in the country. Learning from previous study conducted by Zulfikar (2009), I could not agrre more with him that there is a need to reform the system of education in Indonesia particularly those related to teacher recruitment. Centralisation of the recruiting process would eliminate the authority of the schools to design what sort of persons needed for the existing conditions that are typical in every school. In his Article, Zulfikar (2009) has shown his concern towards the process of teacher recruitment that is highly centralized. The centralization is found to be ineffective due to the effect it brings. Because of the process of recruitment is all in the decision of the central government, schools fail to inquire specific qualities of the teachers that really fit with the characteristics of the schools.In addition to reforming teachers' recruitment system, Zulfikar (2009) promotes evaluations of Indonesian teachers' classroom pedagogy that should be properly and regularly implemented so that teacher-centred classroom pedagogy can be minimised and then abolished in Indonesian education systems. The school should first set the standard of good teaching because attempts to gain academic improvement should come from within the teaching workforce itself (Ingvarson and Chadbourne, 1994). Evaluating teachers is important; it promotes better classroom practices (McLaughlin and Pfeifer, 1988) and it holds teachers responsible for what they teach and why they choose a particular teaching approach (Ingvarson and Chadbourne, 1994). 
Relevant to the idea of making an evaluation for teachers, there are two suggested startegies, namely self-evaluation (Dewey, 1933; McNamara and O'Hara, 2009; Schön, 1983, 1987; Wehmeyer and Field, 2007); and mentoring (Cherian, 2007; McCaughtry et al., 2005; Morton, 2005; Walkington, 2005). The first strategy is self-evaluation (McNamara and O'Hara, 2009) or reflective thinking in Dewey's (1933) and Schön's $(1983,1987)$ term, or self-determination to use Wehmeyer and Field's (2007) term. The aims of this strategy is to provide teachers an autonomous space to look into their own practices and provide feedback on their teaching. For Indonesia, this would be a new way of evaluating teaching. Nevertheless, such an evaluation system needs to gain acceptance in the education community (McNamara and O'Hara, 2009) in Indonesia because of its effectiveness. The basic tenet of selfevaluation is a persistent and a careful consideration of previous teaching experience that enables new teaching insights.

Mentoring is another way of helping teachers achieve their best classroom pedagogy. Mentoring came to prominence in the late 1980s and early 1990s when education reformers believed that on-site assistance would help new teachers adjust to their life in teaching (Cherian, 2007). Mentoring is one-on-one assistance between new teachers and their mentors, senior and successful teachers, which is characterised by a close collaboration between the mentorial specialists and the new teachers. Mentors can guide new teachers in their transition time in their new career and can help them implement their curriculum successfully. Mentors can also provide advice on classroom teaching, and give feedback on the classroom practices of new teachers (McCaughtry et al., 2005).

Self-evaluation and mentoring should both find a place in Indonesian schools. Self-evaluation through reflective teaching, for example, can be implemented for Indonesian senior teachers because they are assumed to have obtained the ability to evaluate their own teaching, although mentoring may be best utilised for novice teachers who have less teaching experience (Walkington, 2005). 
b. Reforming the system for the National Examination (NE)

The National Examination (abbreviated into NE) is the latest form ofa school leaving examination in Indonesia starting from 2005 until now. Itcan be defined as a test to measure and evaluate the students' competencenationally by the central government after the process of teaching andlearning (The Regulation of the Minister of Education 2005, p.1). The NEis implemented as a way of improving national education quality, which issupported by Government Regulation Number 19 year 2005. In its implementation, there are some negative washbacks of the test that generate some critisms from the education practitioners. One of the remarkable washbacks is the use of the test result as the main factor determining pass or not pass. This really bothers the education practitioners as the process that have been carried on within three years is almost neglected.

Some improvements are made for the betterment of the implementation of NE; however, the reality seems difficult to find a completely satisfying interpretation toward the result of the test. Lie (2004) in Zulfikar (2009) severely criticises government policy on national examinations. She contends that the enforcement of the current national examination system implies that the government is displeased with decentralising authority; that the central government intends to maintain control and authority over education management Indonesia-wide (Lie, 2004). This is very sceptical, but it cannot be denied that it is true to some extends. One of the vigorously negative washback is its impact toward teaching and learning process in the classroom. Due to the preparation for NE, there is no better learning startegis than rote learning. Rote learning is considered the best way preparing students to combat with the test content in the national examination. In this article, this matter is then connected to the quality of teachers, by which the teachers who commit using rote learning in their class would completely loose their creativity in modyifng active involvement of the class. They would tend to use more teacher oriented rather than encouraging the active involvement of ebvery member of the class. For such a case, there is no intention to blame the teachers, therefore the article attempt to find a way for reforming the implementation of the test so that throughout the test the quality of teachers can be fostered. 
By definition, the NE can be categorized as a high stake summative asseassment whereas the information of this test would inform student achievement at a certain time. The information provided can be in the form ofinternal school tracking of students' progress; informing parents,students and the students' next teacher of what has been achieved; certification oraccreditation of learning by an external body; and selection for employment or highereducation. It is also used, with other information, for monitoring the performance ofteachers and schools(Harlen, 2005). However, what has so far been employed in the NE denies the nature of an assessment. The NE terrifies not only the students, but teachers and parents are also worried as this is not only used to inform the performance of the students but it can be a threat for the students as it can make them fail to pass from the school. The problem is then lied on the justification that is made so that the process has no meaning for the students. As a consequence, as soon as students are at the third grader in the secondary they prefer to have an extra lesson to prepare the NE. They are exposed in a class where they are trained to work on the test contents. If it does, then what the teachers can do is to provide as many as possible the used test items for the students to accomplish. Then the classroom would be condensed with the activities of working on the practices of paper and test national examination and the discussion on the responses given to each number of the test. Therefore, the idea of making active involvement is no longer applies here.

In the attempt of reforming the asesment system in Indonesia, there is a good reference from Victoria school in Australia on how such a summative testing is employed and it affects teachers in the way that they do not become the party to blame for not able to elicit active involvement of the students in class. As what Zulfikar (2009) has exemplified from one of the schools in Australia state of Victoria, it might be contributing if the assessment system is depicted then learned for improving the system of assessment in Indonesia. The Schools in the Australian state of Victoria do not administer a single examination for a summative assessment; they implement a series of assessments throughout the Victorian Certificate of Education (VCE) school years, that is, Years 11 and 12 (grades 2 and 3 in the Indonesian senior high school system). A summative assessment by a single 
examination is only made in Years 3, 5, 7 and 9 as a source of quality control for the government on school quality. The series of in-class and external assessments in the VCE give a better picture of students' intellectual ability. Indonesian teachers should understand that learning is a process rather than a product; some students understand a lesson more quickly, others need a longer time to gain in-depth understanding. Therefore, judging students' intellectual quality through a single summative assessment does not generate a valid picture of their intellectual capability. The series of assessments as implemented in Victorian schools should find a place in Indonesian schools. Such full assessments throughout the school years allow teachers to learn students' strengths and weaknesses and also enable students to know their abilities and talents.

If the system of assessment in Indonesia could be improved so that process can really take the important place in education, teachers would be one of those who can take the benefits, in the sense that teachers can take the role to elicit the active involvement of the students in class. Making a whole member of the class active requires a specific capacity from the side of the teachers, and those who are able to manange this caan be categorized as the successful ones.

\section{Good Teachers for the Context of Indonesia Classrooms: A Conclusion}

Based on what I have decribed in the previous sections of this article, there, I propose, should be two efforts need to be done, namely reforming the system of teacher recruitment and system of national examination. The reasons of reforming those two prior to fostering the quality of the teachers are due to

1. the recruitment systems effect to the prior capacity of teacher. Centrelized recruitment does not give a space for the school to choose the right person for the place. Say, schools in a rural areas would require quality that is not the same with those in the urban areas. A school where students belonging to the family in the rural areas go to requires teachers who really have passion to motivate their students to school and they should have a good talent of communication needed to enforce parents to let their children to leave work and go to school. This might be far different with the schools in big cities. 
Such schools might require teachers who are highly alert with modernisation or they should be technological literate as the students mostly come from higher level society. If the recruitment is carried on like it is today, it is hard to find good quality for appropriate context, as good at one place cannot be absolutely good for other place.

2. The system of national examination that is need to be improved. There is, in my opinion, an intricate relationship between the system and the quality of the teachers. The system in Indonesia cannot accomodate to enhance the quality of the teachers. In premises, the curriculum is designed in such a way, although keep changing in every succession of the Minister of Education, to improve the quality of education; however, in practices it always ends at the same way. The NE is used as an instrument determining the success of the students, then the process is almost neglected. The teachers could uses various startegies in order to employ the curriculum in class accordingly, but at the end, they have to change drastically for preparing students for the NE. In this case, teachers should present various test contents an exposure for students to face the exam. Therefore, I might say, that the objective of the course is supposed to prepare students to pass. Then, this breaks the nature of active learning but then tend to be rote learning that is against the need of the students to be actively involved in class.

\section{References:}

Azer, S.A., (2005), The qualities of a good teacher: how can they be acquired and sustained?.Journal of the Royal Society of Medicine. Vol: 98, 67-69

Cherian, F. 2007. Learning to Teach: Teacher Candidates Reflect on the Relational, Conceptual, and Contextual Influences of Responsive Mentorship. Canadian Journal of Education, 30 (1), 25-46

Dewey, J.1933. How we Think. New York: DC Health

Ingvarson, L and Chadbourne, R (eds). 1994. Valuing Teachers' Work: New Directions in Teacher Appraisal. Melbourne: Department of Education and Training.

McCaughtry, N, Kulinna, PH, Cothran, D, Martin, J, and Faust, R. 2005. Teachers Mentoring Teachers: a View over Time. Journal of Teaching in Physical Education, 24, 326-343. 
McLaughlin, MW, and Pfeifer, RS. 1988. Teacher Evaluation: Improvement, Accountability and Effective Learning. New York: Teachers College Press.

McNamara, G, and O'Hara, J. 2009. Trusting Schools and Teachers: Developing Educational Profesionalsm through Self-evaluation. New York: Peter Lang.

Schön, DA. 1983. The Reflective Practitioner: How professionals Think in Action. New York: Basic Book

Schön, DA. 1987. Educating the Reflective Practitioner: Toward a New Design for Teaching and Learning in Professions. San Francisco and London: JosseyBass Publishers.

Walkington, J (2005) Mentoring Preservice Teachers in the Preschoool Setting: Perceptions of the Role. Australian Journal of Early Childhood, 30 (1),28-35

Wehmeyer, ML, and and Field, SL. 2007. Self-Determination: Instructional and assessment Strategies. Thousand Oaks: Corwin Press.

Zulfikar, Teuku. 2009. The Making of Indonesian Education: An Overview on Empowering Indonesian Teachers. Journal of Indonesian Social Sciences and Humanities Vol.2, 2009, pp.13-39.URL:http://www.kitlvjournals.nl/index.php/jssh/index

\section{Website}

Connell, R., 2009. Good teachers on dangerous ground:towards a new view of teacher qualityand professionalism. http://www.tandfonline.com/loi/rcse20. Retrieved 10 November 2013.

Daud, ZBM (2009). Mempertanyakan efesiensi UN. Retrieved 1-05-2013, from http://id.acehinstitue.org

Jamil, H, Nordin, A. Razak., Reena, R. and Abdul RM. ." Teacher Professional Development in Malaysia: Issues and Challenges" last retrieved on 10 December 2013

Khalifa, S (2009). UN, formalitas nasional yang irrasional. Retrieved 1-05-2013, from http://id.acehinstitute.org

Lie, A (2004). Tujuan akhir nasional: kesenjangan kekuasaan dan tanggung jawab. Retrieved 15-09-2009, from http://www.komunitasdemokrasi.or.id

Oey-Gardiner, M (2005). Ujian Nasional: Mengukur standar mutu atau 'UUD' Retrieved 15-10-2013, from http://www.ihssrc.com

Soaloon, BT (2009). Dusta ujian nasional. Retrieved 23-10-2014, from http://id.acehinstitute. 